\title{
Monetary Sanctions and Symbiotic Harms
}

\author{
DANIEL J. BOCHES, BRITTANYT. MARTIN॰, ANDREA GIUFFRE®, \\ AMAIRINI SANCHEZ, AUBRIANNE L. SUTHERLAND, AND \\ SARAH K.S. SHANNON(D)
}

People convicted of crime are often treated as atomistic individuals by the criminal justice system, ignoring the fact that they are largely embedded in social networks. Research shows that family members are often negatively impacted by their relatives' punishment despite not breaking any laws themselves. These detrimental effects of punishment on family are known as symbiotic harms. Most research on symbiotic harms, however, has focused on incarceration. We extend this research by describing how monetary sanctions harm the families of adults with legal debt. Our data come from semi-structured interviews with 140 people with legal debt and ninety-six court actors in Georgia and Missouri. We find evidence that family members are often coerced into paying their relatives' fines and fees and that monetary sanctions increase the financial strain, emotional distress, and interpersonal conflict that relatives experience.

Keywords: family, legal financial obligations, monetary sanctions, symbiotic harms

Daniel J. Boches is a doctoral candidate in the Department of Sociology at the University of Georgia, United States. Brittany T. Martin is an assistant professor in the Department of Sociology and Criminology at Western Kentucky University, United States. Andrea Giuffre is a doctoral candidate in the Department of Criminology and Criminal Justice at the University of Missouri-St. Louis, United States. Amairini Sanchez is a doctoral candidate in the Department of Sociology at the University of Georgia, United States. Aubrianne L. Sutherland has a B.A. from the University of California, Irvine. Sarah K.S. Shannon is an associate professor in the Department of Sociology at the University of Georgia, United States.

(C) 2022 Russell Sage Foundation. Boches, Daniel J., Brittany T. Martin, Andrea Giuffre, Amairini Sanchez, Aubrianne L. Sutherland, and Sarah K.S. Shannon. 2022. "Monetary Sanctions and Symbiotic Harms." RSF: The Russell Sage Foundation Journal of the Social Sciences 8(2): 98-115. DOI: 10.7758/RSF.2022.8.2.05. This research was funded by a grant to the University of Washington from Arnold Ventures (Alexes Harris, PI). We thank the faculty and graduate student collaborators of the Multi-State Study of Monetary Sanctions for their intellectual contributions to the project. Partial support for this research came from a Eunice Kennedy Shriver National Institute of Child Health and Human Development research infrastructure grant, P2C HD042828, to the Center for Studies in Demography and Ecology at the University of Washington. We also thank Mark Cooney, Justine Tinkler, and several anonymous reviewers for their comments on previous drafts. Direct correspondence to: Daniel J. Boches, at daniel.boches@uga.edu, Department of Sociology, University of Georgia, 113 Baldwin Hall, Athens, GA 30602, United States; Brittany T. Martin, at brittany.martin@wku.edu, Department of Sociology and Criminology, Western Kentucky University, 100/101 Grise Hall, Bowling Green, KY 42101, United States; Andrea Giuffre, at amg7v9@mail.umsl.edu, Department of Criminology and Criminal Justice, University of Missouri-St. Louis, 324 Lucas Hall, St. Louis, MO 63121, United States; Amairini Sanchez, at amairini.sanchez@uga.edu, Department of Sociology, University of Georgia, 113 Baldwin Hall, Athens, GA 30602, United States; Aubrianne L. Sutherland, at alsuther@uci.edu; Sarah K.S. Shannon, at sshannon@uga.edu, Department of Sociology, University of Georgia, 113 Baldwin Hall, Athens, GA 30602, United States.

Open Access Policy: RSF: The Russell Sage Foundation Journal of the Social Sciences is an open access journal. This article is published under a Creative Commons Attribution-NonCommercial-NoDerivs 3.0 Unported License. 
People convicted of crime are often treated as atomistic individuals by the criminal justice system, ignoring the fact that they are largely embedded in social networks (Comfort 2007). They are mothers and fathers, sons and daughters, brothers and sisters, friends and partners. Research has shown that the pains of punishment endured by justice-involved individuals are not theirs alone but radiate to and have a negative impact on their social ties. Through indirect and direct interaction with the criminal justice system, such as witnessing arrests and visiting loved ones in prisons and jails, family and friends "who have no warrant out for their own arrest, face no criminal charges, and receive no sentence for confinement ... undergo conditions very similar to those of people charged with or convicted of a criminal offense" (Comfort 2007, 275). Rachel Condry and Shona Minson (2020) refer to the negative effects of punishment on family as symbiotic harms. Most research on symbiotic harms has focused on incarceration (Comfort 2016, 64). We extend this research by describing how monetary sanctions - criminal justice fines and fees-harm the families of adults with legal debt. We use family to describe the kin relationships of justice-involved individuals; this includes their parents, siblings, children, spouses, grandparents, and other extended family. This conceptualization of family is an ideal type, however. Thus, in practice, family may also extend to close friends and nonmarried partners (Condry and Minson 2020, 2).

Extending research on the negative effects of punishment on family to consider the impact of monetary sanctions-also known as legal financial obligations (LFOs) -is essential for two reasons. First, monetary sanctions are vast in scope. Fines and fees are one of the most common forms of punishment, assessed for a variety of offenses at both the misdemeanor and the felony level (Harris, Evans, and Beckett 2010; Martin et al. 2018). Second, the costs of monetary sanctions easily spread through social networks. Fines and fees, "alone among modern punishments, effectively dispense with the requirement that the offender bear the burden of the penalty" (Quilter and Hogg 2018, 15). People cannot be put on electric home monitoring, perform community service or attend driving school, or serve a jail or probation sentence on behalf of a family member. However, people can and frequently do pay their relatives' legal debt, often shifting this burden to poor families (Katzenstein and Waller 2015). In short, the vast scope and transferable nature of contemporary monetary sanctions function to stretch the costs of fines and fees far and wide, making it necessary to investigate how LFOs harm family and friends. These impacts are especially consequential for families with fewer economic means. Data for our analysis were derived from semi-structured interviews conducted in multiple sites across Georgia and Missouri between 2016 and 2018. We find evidence that family members are often coerced into paying their relatives' fines and fees and that monetary sanctions increase the financial strain, emotional distress, and interpersonal conflict that relatives experience.

\section{SYMBIOTIC HARMS OF PUNISHMENT}

Symbiotic harms refer to the unintended negative effects of punishment on the intimate associations of justice-involved individuals, specifically family (Condry and Minson 2020). "Harms are symbiotic when they are enmeshed and entwined within connections to others and are more than vicarious - the experience of the harms is altered by the symbiosis" (9). Because of the interdependence that characterizes the relationships between people convicted of crime and their kin, punishment harms felt by justice-involved individuals can have an impact on family and vice versa. Symbiotic harms are characterized by "their relational, mutual, nonlinear, agentic, and heterogeneous properties" (2). Relationality refers to the fact that justiceinvolved individuals have relationships with kin and state punishment, but also that family has a relationship with the criminal justice system. Mutuality refers to the ongoing process by which harms caused to people convicted of crime influence family and vice versa. Nonlinearity refers to the multiplicity of ways that harms are experienced in their character and intensity over time. Agency refers to purposeful action by families as they negotiate punishment harms and relationships. Last, heterogeneity refers to how harms can be differently experienced. As currently conceptualized, the 
logic of symbiotic harms can subsume much of the literature on the negative effects of punishment on family.

Most of the research on symbiotic harms focuses on incarceration, and most of the research on incarceration focuses on relatives' indirect interaction with the criminal justice system. For example, incarceration has been shown to heighten the risk of divorce or separation (Lopoo and Western 2005). The intimate partners of incarcerated men also experience significant economic hardship (Carlson and Cervera 1992). Sheri Walker (2011) finds that women who have incarcerated partners are more likely to receive welfare and food stamps than those who do not. This hardship is likely to persist on reentry given the negative effect of a criminal record on obtaining employment (Pager 2003). The incarceration of parents can negatively affect children as well, resulting in an intergenerational transmission of prison disparities. For example, research has connected parental incarceration to detrimental outcomes in children such as lower educational achievement (Hagan and Foster 2012), heightened physical aggression (Wakefield and Wildeman 2011), and a greater risk of ending up in foster care (Swann and Sylvester 2006). The family of those incarcerated also confront unique health risks. For example, incarceration has been shown to worsen maternal mental health (Wildeman, Schnittker, and Turney 2012). Research also demonstrates that young women who have experienced parental incarceration report a higher body mass index than their counterparts whose parents have not been incarcerated (Roettger and Boardman 2012). The negative consequences families confront due to punishment are not isolated to indirect interaction with the criminal justice system, but also occur through direct contact.

Research demonstrates that partners and children are often subjected to uncomfortable experiences when visiting loved ones in prisons and jails (Aiello and McCorkel 2018; Christian 2005; Comfort 2007, 2008). They experience physical searches, long periods of waiting, and the prohibition of certain personal belongings (see Comfort 2007, 278). Inside prisons, family and friends are compelled to engage in regimented behavior like those who are incarcer- ated. They are "subjected to the same scrutiny, general withholding of information, required obedience of institutional rules, and periodic reminders of their subordinate status" (Comfort 2007, 278). On release, partners may also experience invasions of privacy, including having their cars and homes searched by police and parole officers (Comfort 2008, 190). Alice Goffman (2014) finds evidence of partners and mothers of young men "on the run" in Philadelphia having their homes broken into, belongings damaged, and bodies shoved to the ground by law enforcement. These women were directly threatened with arrest, eviction, and having their children taken away by police if they did not provide information that could lead to the whereabouts of the legally precarious men in their lives. In short, family and friends are frequently harmed by punishment through indirect and direct interaction with the criminal justice system. However, most of this research has focused on incarceration, investigating the most extreme effects of deprivation of liberty on family (Comfort 2016, 64).

\section{EXTENDING SYMBIOTIC HARMS TO MONETARY SANCTIONS}

By focusing on the effects of incarceration on family, most other forms of punishment, such as monetary sanctions, have largely been ignored. However, monetary sanctions are vast in scope. In the modern U.S. criminal justice system, monetary sanctions are one of the most common forms of punishment, assessed for a variety of offenses at both the misdemeanor and the felony level (Harris, Evans, and Beckett 2010; Martin et al. 2018). Further, LFOs are unique among modern state sanctions in that the direct costs of fines and fees can be endured by people other than the convicted person (O'Malley 2013). For example, a family member cannot serve time in jail on behalf of a relative but can pay their fines and fees. Julia Quilter and Russell Hogg explicitly draw a distinction between LFOs and other state punishments when they write that "The law requires payment [of monetary sanctions], but is indifferent to who makes it. Unlike other penal sanctions, which are personal in nature, the costs imposed by money sanctions are transferable" $(2018,15)$. The vast scope and transferable na- 
ture of contemporary monetary sanctions function to stretch the costs of fines and fees far and wide, beyond those convicted of crime. As a result, it is essential to study how LFOs harm the relatives of justice-involved individuals.

People often pay the legal debt of their relatives (Katzenstein and Waller 2015). This includes a variety of costs, such as commissary and telephone fees accrued while incarcerated; court, probation, and jail fees; ankle monitor and drug treatment fees; and restitution. Lily Gleicher and Caitlin DeLong (2018) find that more than half of respondents in a survey of 269 people with legal debt borrowed money from family or friends to pay their LFOs. Likewise, Foster Cook (2014) examines survey data across thirteen counties in Alabama and finds that 55 percent of the 920 respondents relied on family and friends to help pay their legal debt.

Although disparate studies provide examples of parents, grandparents, children, siblings, and partners paying monetary sanctions, research also shows that women relatives-especially mothers - are most likely to pay someone else's LFOs (deVuono-powell et al. 2015). For example, a recent study of commercial bail finds that "Poor women of color ... stand at the center of predatory bail targeting" (Page, Piehowski, and Soss 2019, 159). Defendants rarely have enough resources to enter bail contracts by themselves. As a result, the women in their lives, often mothers, become cosigners, which exposes them to considerable financial liability. Leslie Paik and Chiara Packard (2019) draw on interviews with young people convicted of crime and their parents, focusing on juvenile justice fines and fees, not adult defendants. They find that LFOs harm relatives by increasing negative emotions, financial strain, and family conflict. In short, monetary sanctions tether both justice-involved individuals and their legally innocent relatives to the criminal justice system (Harris 2016, 72; see also Fernandes, Friedman, and Kirk 2022, this volume; Huebner and Giuffre 2022, this volume; O'Neill, Smith, and Kennedy 2022, this volume; Sanchez et al. 2022, this volume), placing them at risk of being surveilled and harmed by agents of the state.

We contribute to the literatures on symbi- otic harms and monetary sanctions by seeking to answer the question of how monetary sanctions harm the families of adults with legal debt. Specifically, we focus on the methods families use to pay, the ways that court actors leverage social networks to extract LFO payments, how these dynamics contribute to conflict within families and between family members and agents of the state, as well as what happens when individuals do not have family support to draw on.

\section{RESEARCH DESIGN}

The data for this study were derived from semistructured interviews with 140 people with legal debt and ninety-six court actors-judges, attorneys, clerks, and probation officers-in Georgia and Missouri. As part of the larger Multi-State Study of Monetary Sanctions, all interviews were conducted between 2016 and 2018 (for more information on the research design of the larger project, see Harris, Pattillo, and Sykes 2022, this volume).

Interviews with people assessed fines and fees and court actors were conducted across thirteen field sites. In Georgia, research was conducted in three counties-a large urban county, a moderate-sized county, and a small rural county-and three cities within those counties. Each of the three counties has a superior court (felonies), a magistrate court (arraignments), and a probate court (traffic and some misdemeanors). The large urban county also has a state court that handles traffic and misdemeanor offenses (instead of the probate court, which handles only civil matters). Each of the three cities has a municipal court that handles traffic offenses, misdemeanor offenses, and city ordinance violations. In Missouri, interviews were conducted in seven field sites: a large urban city and two rural counties, each with a circuit court, and four areas each with a municipal court. Missouri has forty-five circuit courts, which are the primary trial courts and typically operate from the county seat. Circuit courts adjudicate misdemeanor, felony, and civil cases with divisions for general, juvenile, drug, and traffic courts. Within the circuit courts, municipal courts operate as special divisions and hear traffic and city ordinance violations. 
Data from both Georgia and Missouri were included in this analysis because they have several key similarities, including court structures, the criminalization of traffic violations, and the use of private probation companies to supervise people convicted for misdemeanor offenses (Huebner and Shannon 2022, this volume). That said, in Missouri, some parking and traffic offenses are classified as noncriminal infractions but are still processed by the courts and engender many of the same surcharges as criminal offenses. In terms of monitoring and collecting LFOs, probation officers in Georgia are largely responsible for both tasks; in Missouri, the courts (through clerks and online payments) and private collection agencies collect LFOs and probation officers track how much people owe and evaluate their ability to pay. Given the nonrandom nature of our interview data, we do not seek to make comparisons between states or any other groups. Instead, we aggregate our data, seeking a general understanding of how people describe how LFOs harm families.

Our sample of people with legal debt is diverse along several demographic characteristics (see table 1). Participants range in age from eighteen to seventy, the median being thirtysix. Two-thirds of our sample are men (66 percent) and one-third are women (34 percent). The split is almost even between participants who identify as White (43 percent) and those who identify as Black (47 percent), far fewer identifying in other racial categories (10 percent). At the time of the interview, 42 percent of the sample was employed. Exactly half of the sample had both a misdemeanor and felony level conviction. Regarding monetary sanctions, the median amount of LFOs assessed among respondents falls between \$2,001 and $\$ 3,000$. For comparison, the median monthly household income for interviewees with LFOs ranges between $\$ 1,001$ and $\$ 1,250{ }^{1}$

The sample of court actors also varies by de- mographic characteristics (see table 1). More than half of the court actors we interviewed were judges and probation officers, 31 percent and 24 percent of our sample, respectively. The remainder of our court actor sample comprises defense attorneys (19 percent), prosecutors (10 percent), and clerks (16 percent). An overwhelming majority identify as White (84 percent). Racial diversity in our sample of court actors from Georgia was slightly higher than that in Missouri, however. Men and women comprise 47 percent and 42 percent of our court actor sample, respectively. Finally, the median age for our sample of court actors is fifty.

All interviews were conducted in person. These interviews were audio recorded and subsequently transcribed. ${ }^{2}$ Once transcribed, they were imported into the qualitative software program NVivo. The coding process occurred in two major phases. The first round used a closed coding approach based on an established coding scheme created by the team of researchers on the Multi-State Study of Monetary Sanctions and implemented in all eight states. These closed codes included broad categories such as employment and personal networks. Researchers from each state read each interview line by line, sorting relevant aspects of the interview transcripts into their respective nodes, first for the interviews with people who were assessed LFOs then for those with court actors.

After the initial round of coding, we continued the coding process with the interview transcripts. To capture instances and perceptions of familial harm as it relates to LFOs, we ran a matrix coding query in NVivo, delimiting our Georgia interview data with people who owe legal debt to examine where text was coded in both the personal networks node and (one or more of) the six LFO nodes. The personal networks node includes, among other things, general or specific conversations about a respondent's personal network or lack of personal network such as their family mem-

1. The median amount of LFOs assessed and median monthly household income were computed after excluding missing data and "I don't know" responses.

2. This was true for all 140 interviews with people assessed fines and fees and ninety-four (of the ninety-six) interviews with court actors. Two judges in Georgia did not consent to being audio recorded. In these two cases, the interviewer took handwritten notes during the interview and subsequently typed their notes in narrative form for later analysis. 
Table 1. Interview Sample of People with Debt and Court Actors in Georgia and Missouri, by Demographic Characteristics

\begin{tabular}{lcccc}
\hline Demographic & People with Debt & Percentage of & Court Actors & Percentage of \\
Characteristics & $(N=140)$ & People with Debt & $(N=96)$ & Court Actors
\end{tabular}

\section{State}

Georgia

60

42.86

50

52.08

Missouri

80

57.14

46

47.92

Age

$$
\text { 18-29 }
$$

32.86

3.13

30-39

28.57

22.92

40-49

20.71

11.46

50-59

16.43

29.17

60-69

0.71

9.38

70-79

0.71

3.13

No response

0.00

20.83

\section{Race}

White

60

42.86

47.14

Black

66

$\mathrm{Bi}$ - or multiracial

3.57

Other

6.43

No response

0.00

\section{Gender}

Man

65.71

Woman

33.57

84.38

Transgender

0.71

No response

0

0.00

81

11.46

11

1.04

2.08

1.04

\section{Marital status}

Never married

Living with partner

12.14

Married

12.14

Separated-divorced

15.71

23

Widowed

16.43

2.86

\section{Employment status}

Employed

Unemployed

59

81

\section{Conviction type}

Felony

Misdemeanor

Both

No response

Job title

Judge

Prosecutor

Defense attorney

Court clerk

Probation officer
42.14

57.86

28.57

15.71

50.00

5.71
41.67

0.00

11.46

Source: Authors' calculations. 
bers. The LFO nodes capture all conversations about the payment of legal debt, consequences for nonpayment, alternatives to payment, restitution, legal support, and specific costs associated with criminal justice contact such as urine analysis tests and bail. We engaged in open coding, identifying themes relevant to familial harm and LFOs in the interview transcripts (Emerson, Fretz, and Shaw 2011). With these themes in mind, we then engaged in focused coding and wrote integrative memos seeking to connect disparate data and establish clear subthemes (Emerson, Fretz, and Shaw 2011). We used the patterns identified in our analytic memos to inform the subsequent coding of the interviews with people who owe LFOs from Missouri. To ensure that we did not miss any important themes specific to Missouri, we also inductively coded the Missouri data. This coding process was repeated for the court actor interviews, with one exception. Rather than performing a matrix query in NVivo, we simply recoded the data located in the debtor networks node from the first round of coding. This node includes, among other things, instances when a respondent talks about debtor or defendant personal networks (family, friends).

\section{HOW FAMILIES PAY}

\section{MONETARY SANCTIONS}

In the analysis of the interview transcripts with people who owe LFOs, we counted fifty-seven unique instances when the interviewees clearly identify the family member who provided the financial support, whether direct or indirect. Direct support refers to money from friends or relatives for the payment of the fines and fees. Indirect support refers to support in the form of housing, childcare, transportation, or money for monthly bills. It often helps people who owe legal debt by allowing them to allocate their money to the payment of their fines and fees. In these cases, financial support can function as an indirect payment of LFOs. Of the instances of financial support counted in the transcripts, most (33 percent) entailed support from mothers, followed by partners (23 percent), fathers and siblings (12 percent each), friends and other (7 percent each), and children (5 percent). ${ }^{3}$ These findings mirror other research showing that women often bear the brunt of the impacts of monetary sanctions (see, for example, O'Neill, Smith, and Kennedy 2022 , this volume). Research shows that mothers provide the most support to people with legal debt (deVuono-powell et al. 2015) and women, specifically mothers, grandmothers, and sisters, provide the most financial support to formally incarcerated people upon reentry (Western et al. 2015). ${ }^{4}$

The analysis of our interview transcripts provides insights not only into which family members pay LFOs, but also into how they pay. Like their justice-involved relatives, family and friends often experience difficult financial situations. As Nia, a thirty-seven-year-old Black woman, told us, "My mom, she tends to help me some, but she has her own bills." ${ }^{5}$ As a result, acquiring the money to pay their relatives' fines and fees is not easy and functions as a major social stressor (Harris and Smith 2022, this volume). We found that families are often forced to rely on burdensome strategies to help pay legal debt, including taking out loans, using tax refunds, and pawning valuable assets (deVuono-powell et al. 2015).

In one case, Josh, a twenty-seven-year-old White man, relied on his mother's help on multiple occasions. Eventually she was able pay off the remainder of his debt from the time he was convicted for driving with a suspended license.

3. If respondents said their parents provided support, we counted it as support coming from both a mother and father. The categories mother and father include support from stepmothers and stepfathers, respectively. Partner includes support from married partners, nonmarried partners, former partners, and co-parents. Other included instances of support from an uncle, a grandmother, the parent of a nonmarried partner, and the nonmarried partner of a parent. In three instances, financial support was provided by a nonfamily member: a co-worker, fellow incarcerated person, and stranger. These cases were excluded.

4. For more on family support, particularly from women, for people who experience low-level criminal justice involvement, see Comfort 2016.

5. All names in this article are pseudonyms. 
But before she did so, she kept him out of jail, paying his bail by pawning the title of her car even though she was only weeks away from paying off her car loan. The original focus of this study did not include bail as a monetary sanction. However, many respondents, especially those assessed legal debt, discussed it when asked open-ended questions about their experiences with LFOs and family assistance. We therefore decided to include discussions of bail in the analysis.

JosH: My mom's actually kept me from going to jail by pawning her title to her car.

INTERVIEWER: Was that to pay bail or how did she help you?

JosH: Yeah, well that was to pay my bondsman because I went to show up for court and he put me in handcuffs. He said, "You're not going to court. You're going to jail."

INTERVIEWER: Oh WOW.

JosH: Yeah, she talked to him. He took me to his office. My mom come up there with the money and paid it off.

INTERVIEWER: Wow. She definitely helped you out pretty big time then?

Josh: Yeah.

This put significant stress on Josh's mother, a symbiotic harm she otherwise would not experience. She needed the money for herself, but Josh was unable to pay her back. It became a source of financial and personal strain, as she asked about the money, according to Josh, almost 24/7. During another interview, this time with a probation officer, we were told that some families may be so desperate to pay their relatives' fines and fees that they are forced to rely on their retirement savings: "a number of [people with debt] count on their parents still for some level of support. ... People cash in their retirement." In another case, Marie, a forty-twoyear-old Black woman, said that she was relying on her daughter's income tax refund to pay her LFOs.

MARIE: And my daughter said once she gets her taxes this coming year she's gonna go ahead and pay it all off.

INTERVIEWER: Oh wow. So, your daughter's gonna help you pay it off?
MARIE: Yeah. Pay it off so when I get ready to get off probation I won't have that over my head.

INTERVIEWER: Nice. And is she gonna want you to pay her back or is she just gonna ... MARIE: No, she's sweet. No. Because I do everything that I can do for my kids.

Although some family members provide financial support without expectation of repayment so their relatives with legal debt do not have to pay their fines and fees, others function as a source of credit. In other words, family members will directly pay a relative's fines and fees, but demand to be repaid. For example, Kevin, a twenty-three-year-old White man, relied on help from his girlfriend's mother to make his payments. As a result, he paid her, not probation. "I mean I don't have a credit card so I use my girlfriend's mom's credit card. I just give her the cash and she did it for me." The same logic guided part of the payment of Gwen's debt. In addition to paying probation, Gwen, a twenty-eight-year-old White trans woman, also paid back her father by working for him.

INTERVIEWER: Most of how you were able to pay it off, it sounds like, it came from you working jobs. Did you have any other outside help? Family or friends?

GwEN: Yes, my dad.

INTERVIEWER: Okay.

GWEN: Yes, ma'am.

INTERVIEWER: How did he work it out with you? Did he...

GwEN: He said I owed him money. He would be like, you're coming to work with me like I do, Monday through Friday. I'd go . . . with him and I work for him all week.

INTERVIEWER: In a way working for him you're still kind of paying down the debt with him?

GWEN: Yes.

INTERVIEWER: Just not with the state?

GWEN: I work for free, yes. Yes.

The process of borrowing from others and relying on credit cards to make LFO payments effectively "converts the public obligation into a private contractual one, a private debt" (Quil- 
ter and Hogg 2018, 15). Using credit cards to pay legal debt also runs the risk of accruing interest, possibly resulting in a larger bill overall. Furthermore, if this debt goes unpaid, it has the potential to lower credit scores and foster housing instability among justice-involved individuals and their relatives (Huebner and Shannon 2022, this volume; Pattillo et al. 2022, this volume).

In sum, like people who owe LFOs, family members often find themselves in financially precarious situations. As a result, they often rely on onerous strategies to acquire money to pay their relatives' fines and fees. This can take the form of emptying their retirement accounts, pawning car titles, using tax refunds, or creating repayment plans. Regardless of how families pay, monetary sanctions function to harm the kin of people convicted of crime by exacerbating financial strain and economic hardship.

\section{HOW FAMILIES ARE LEVERAGED TO COLLECT MONETARY SANCTIONS}

Although family members do frequently pay their relatives' fines and fees, the extent to which their payment is voluntary varies. For instance, some family members may be entirely unencumbered in the payment of a relative's LFOs; others, like Josh's mother, may be less free because they are constrained by economic circumstances themselves. Others still may have little to no choice over their payment of a relative's fines and fees due to pressure from court actors (Paik and Packard 2019, 21-22). Interviews with probation officers revealed clear evidence that families pay legal debt as a result of such pressure. Probation officers told us how family was, is, and should be leveraged to collect LFOs. In the process of leveraging family to collect legal debt, probation officers often pressure family by threatening and using force (such as incarceration) against their justiceinvolved relatives if fines and fees go unpaid. In this way, families are harmed, not just by the financial burden of LFOs, but also by the coercion and strain accompanying contact with probation officers. For example, a White probation officer with twenty years of experience talked about how he and his colleagues used to put pressure on family members in order to collect monetary sanctions: "Back in the day when you didn't have all these programs you have now to put people through, it pretty much if we want to jack you up, we just get you a pretty hefty fine and you had to pay it one way or another. Then again, when it ends up happening you put pressure on the family 'cuz they're the ones got to come up with the money."

Another White probation officer told of a similar pattern. In response to a question about changes to the amounts assessed and the process for recouping legal debt over the past thirteen years, he explained that he used to put people in jail when they could not pay their LFOs in order to pressure family members to pay on their behalf.

I think if anything ... back when I started, we were a little more harsh on fee payments and fine payments and other payments, and in fact, very quickly to get yourself into some trouble as an offender would be to get 90 days or more behind, so I think about $\$ 90$ at that time ... and we'll occasionally have little pushes from parole folks, you know, "Let's get all these people that are behind on fees, and lock them up and let the family come and pay that fee off and that can be their money to get out of jail."

By evoking the specter of incarceration, this probation officer appears to have used state force to induce people to pay their relatives' fines and fees. Mary Pattillo and Gabriela Kirk (2020, 66-70) argue that the use of force, especially threats of incarceration, to collect legal debt is extortion. However, they discuss only how court actors extort money directly from people who are assessed fines and fees. Our data build on this observation by showing that state force is also deliberately used to extort money from legally innocent family members.

We also found that this technique is still used, corroborating evidence from a recent $\mathrm{Hu}$ man Rights Watch report on probation (AlbinLackey 2014) and extending scholarly research on the strategies that probation officers use to collect LFOs (Ruhland 2020). For example, a probation officer told us that he currently leverages relatives to recoup monetary sanctions, calling them at their homes with the goal of 
convincing them to pay. This probation officer also told us how he talks to families about the legal troubles facing their relatives because he knows sometimes they "ain't painting the whole picture." This tactic may function to sow distrust between people with debt and their families.

A lot of times, I'll tell the defendant to ... talk to family members and they won't do it ... So, I'll get the phone number, I'll talk to them. I'll say we need your help here. If both parents say I don't have the money, I'm retired, I'm on Social Security whatever, so on and so forth. I just say well, I just need to let you know what we're dealing with here 'cause I know sometimes your son or daughter ain't painting the whole picture for you. You need to understand what they're up against. If you can help, or somebody else can, then certainly we can do that.

Threats of force for nonpayment are included in these telephone calls. "I will call up family members ... I say listen, Jane here is telling me she can't make these payments, I'm very concerned 'cause I'm gone take her back before the court and she don't comply, I don't know what the court's gonna do here." Because of these threats, family members perceive that if they do not pay their loved one's fines and fees then their relative may be incarcerated. That was the stated motivation for why Alice's daughter, Jasmine, paid her LFOs. Alice, a fortysix-year-old Black woman, related the following exchange:

ALICE: My daughter paid . . . for me. She came to court and made an agreement with the judge that she would pay it off and they let me out on probation.

INTERVIEWER: So, the payments . . Y You said your daughter was helping you. ... She paid the $\$ 100$ a month?

ALICE: She paid it. She paid it ... She paid it for her mommy. Yes ... She didn't want me to go to jail and you know, she looked out for me. She know I didn't have anything.
In short, extortion is not a relic of the past but instead an enduring feature of the monetary sanctions regime.

Besides contacting family directly and threatening force if LFOs go unpaid, court actors in some cases can simply transfer funds away from family to be used toward the payment of legal debt. For example, in many states, including Missouri, money deposited into commissary accounts by family members can be legally diverted to pay monetary sanctions (Katzenstein and Waller 2015). ${ }^{6}$ During our fieldwork in Missouri, a White probation officer with nineteen years of experience told us how he legally diverts money, provided by family, away from commissary accounts to be used instead toward the payment of fees. This often engenders a flurry of letters from people in prison wondering where their money has gone. "Especially the first time mom sends in 100 bucks and $\$ 3$ goes to their canteen, because we hold the other $\$ 97$, then they're pretty ticked. And also, I'll start getting calls from mom.... Yeah, she'll like, 'I'm sending this money and y'all are keeping it.' I can't discuss the fees with mom, 'This is his deal. You need to talk to him about it."”

In addition to telling us how he legally diverts money away from families to pay relatives' fees, this probation officer also told us that when family members are concerned about their money being taken and used for purposes they did not agree to, he is not obligated to talk to them. As a result, although family members can be leveraged by the state, often coercively, to pay someone else's LFOs, they have no form of formal recourse for expressing their grievances.

Leveraging family has been used in the past as well as in the present to collect legal debt, but it also is perceived as a viable technique for the future. One probation officer told us that he wished he had more authority to coerce relatives into paying LFOs. Again, the tactic he describes is extortion. "If we had the leverage we had years ago it might make it little bit easier, at least we think that in our minds. It used to work a long time ago. . . . I'd 
like to see the courts, probably maybe use a little bit more. Here again, put them in jail two or three weeks, just to see if that would work. See if any family members would come up with some money. I think we could get some money that way."

In sum, probation officers frequently leverage relatives to collect legal debt. Family members often lack agency as probation officers pressure them to pay. If families cannot pay, their loved ones may be threatened with force (such as incarceration). This tactic is not isolated to the distant past, but actively used and considered a viable technique for the future. In short, families are coerced, often positioned as targets of extortion by probation officers. We also found that in some cases court actors may simply divert familial money away from commissary accounts to be used instead toward the payment of LFOs. As true of exploiting welfare clients' social networks in fraud investigations (Headworth 2019), appropriating social ties to enforce payment of LFOs is ubiquitous. The use of social ties to collect fines and fees results in many harms against families beyond economic hardship such as emotional distress and strained and fractured relationships. In particular, monetary sanctions harm families by causing interpersonal conflict.

\section{HOW MONETARY SANCTIONS CAUSE CONFLICT}

Interpersonal conflict is often a function of criminal justice contact. In her fieldwork, Alice Goffman (2014) finds that the partners and mothers of young men "on the run" are often threatened by law enforcement, subsequently sowing fear and strain in the relationships of these young men. Likewise, being assessed legal debt and relying on support from family is shown to lead to stress, anxiety, strained relationships, and conflict within families (Harris 2016; Kaplan et al. 2016; Paik and Packard 2019; Pleggenkuhle 2018). For example, a White probation officer explained that defendants often rely on family to pay their legal debt. However, as we described earlier, family members rarely have extra money that they can allocate toward the payment of a relative's fines and fees. This dilemma can lead to conflict within the family.
People that are really struggling and they have to go to their family members, obviously that's definitely some tension there because some of these families don't have the money to give them.... A lot of these families, court costs ... and stuff like that, some of these families don't have that money to pay for their children, their babies, and you can tell it drives some tension. Especially when I receive calls from mom like, "Why is my baby incarcerated? How am I going to pay for him to get out?" Stuff like that. There's definitely some friction.

As this respondent recounted, relatives sometimes experience tension and friction in their relationships because payments are due, but they are unable to provide adequate financial support to their loved ones with fines and fees. As a result, some family members try contacting court actors, emotionally seeking help regarding the payment of their relatives' legal debt. Monetary sanctions can also provoke conflict between people with LFOs and family because money that was previously used for shared household expenses gets reallocated toward the payment of fines and fees. For example, Rick, a thirty-nine-year-old White man, told us that he would often get into disagreements with his mother and sister because his LFOs hindered his ability to pay his share of the rent and other bills.

I was living with my mother. I was thirty years old, thirty-five years old ... I'd go home to my mother and my sister. They want money for rent. They want this, that, and the other. I was a waiter at the time, so I'd go get a new job... I wouldn't have enough money to give my mom and them, satisfy them on their needs. I tried to explain that to them, "Well, I gotta get this fine back on track." At the end of the day, I'd save eight or ten bucks to go get a fifth of vodka to relieve my stress. I'd give my mom and my sister . . . a couple hundred dollars, save up a few dollars to go give [city X] their 50 bucks or $\$ 75$ or $\$ 100$, whatever I had given them. Then I'd go sit in the basement. I'd start to get drunk. My mom would come down and she'd find me getting drunk. Then she'd be like, "I don't want to 
have fucking alcohol on my property. You should've gave me that $\$ 10$. We got bills to pay, blah blah blah." What would she do? She'd call the cops. "I don't want him here." The cops would come. What would happen? I'd get arrested. What would happen? I'd get charged with trespassing. Off to jail I go. I get another fine. Then it was just problem after problem.

Rick's experience reveals the intricate relationship between legal debt and family conflict, and also how these factors influence people's housing situations. In their article on the housing instability and LFO nexus, Mary Pattillo and her colleagues (2022, this volume) argue that housing instability can lead to family and household conflict, which can in turn lead to criminal justice contact and LFOs. These LFOs subsequently function to worsen credit and hinder people's ability to save resulting in further housing instability. Our data, however, demonstrated by Rick's story, show that the causal arrow can also run in the opposite direction. Specifically, LFOs can lead to housing instability through family conflict. Housing instability in turn results in more LFOs. Rick's legal debt made it difficult for him to contribute to household expenses. This frustrated his family, especially his mother. Combined with Rick's drinking, the frustration his mother felt about their financial situation boiled over into conflict. Rick was kicked out of his house and subsequently arrested, saddled with even more fines and fees.

A prosecutor told us that his years of experience showed him that "It's not uncommon for family members to be involved in the payment of fines.... It wouldn't surprise me if there's some intrafamily conflict that results from a family member lending ... money." This is especially true in the case of posting bond, as we saw with Josh's mother. Rather than waiting in jail for an arraignment, defendants can post bond. This burden, however, often falls on family members, especially mothers (Page, Piehowski, and Soss 2019). Family and friends will vouch for their relatives, posting the money needed to get them out of jail and ensuring that they will be present for their arraignment. Sometimes, however, defendants will take advantage of this support by absconding from their court appearance after their release. Families are subsequently left on the hook, "bring them to court or you're paying their fine for them" a prosecutor told us. This often leads to conflict.

I have seen situations where a family member will post a property bond for somebody and then that somebody takes off. So then they get this nice, lovely letter from the court that says, "Hey, just so you know, the person you assured would be in court and you posted your property against did not show up for court. Do you want to come in and pay cash for that or do you want us to file a lien against your property?" And then the family has to deal with that ... I've had the experience of hearing from those folks that are like, "Yeah, nephew Johnny, I can't believe that [son of a bitch]. I bailed him out of jail and then he took off with his girlfriend to Seattle and we've never heard from him since," or whatever.

Legal debt causes conflict not only between justice-involved individuals and their family, but also between legally innocent family and court actors, extending the reach of the criminal justice system into the household. In Missouri, family is often used to assess whether justice-involved individuals are able to pay their monthly probation fee. A probation officer told us that it is policy across the entire state of Missouri to collect financial documentation reporting the income of every family member who lives with the individual they are supervising. This includes any relative by blood or marriage such as parents, grandparents, spouses, siblings, and children. If a household's total income is above the federal poverty guidelines, the individual's fees cannot be waived. ${ }^{7}$ The probation officer said, "our definition based on the agency's policy is the household income... so everybody in the house, you gotta get the check stubs from them to verify the income to determine if the household is indigent and 
can't pay." This process can result in conflict between legally innocent household members and court actors: "If [people who owe LFOs] bring in documentation, their household income and it shows they're indigent, we enter the waivers ... Now if they refuse to bring it in, we can't waive that because they're expected to bring that documentation. We've had resistance from quite a few people, because the people in their household think it's none of [our] business, 'None of the state's business what my income is,' so they won't bring those waivers in. So we do get quite a bit of resistance from people on that."

Notice that despite the power probation officers wield, family members still try to exercise some degree of agency, engaging in informal "resistance to some of the damaging effects" of monetary sanctions (Condry and Minson 2020, 12). This is clearly articulated when the respondent describes how probation officers face "resistance" from family in response to the use of household finances as a method for determining a justice-involved individual's ability to pay.

In sum, monetary sanctions often cause interpersonal conflict within families. People with legal debt and their families rarely have extra money that can be allocated toward the payment of fines and fees. As a result, tension and frustration builds as families try to pay monetary sanctions and other expenses, such as rent. Legal debt also fosters friction between family and court actors. In short, interpersonal conflict is another harm families endure because of fines and fees.

\section{WHEN FAMILY IS ABSENT}

When people with LFOs cannot pay their fines and fees, family often picks up the slack. However, not everyone has social ties they can rely on to help pay their legal debt. When family support is unavailable, justice-involved individuals face additional pressure, functioning to sustain and reproduce inequality. Alexes Harris (2016) makes this point when discussing deferred prosecution. Deferred prosecution refers to clearing a defendant's criminal record upon successfully completing an entire sentence, including paying all legal debt, within one year of conviction. This is much easier for people who have resources and family support than for those who do not. "Someone who has a stable income or whose family members have wealth can afford to fulfill his or her legal and financial obligations within one year and qualify for a deferred prosecution" (66). Those who lack family assistance, however, tend to get trapped in a cycle of perpetual criminal justice contact.

A fifty-one-year-old White defense attorney mentioned family support when he told us the strategies people use to pay their fines and fees. He specifically mentioned that without help from family and friends, people who owe LFOs are often disadvantaged.

INTERVIEWER: So, for defendants in these situations, what do they rely on most, would you say?

DEFENSE ATTORNEY: Friends and family for the most part.

INTERVIEWER: Does that seem to work for them?

DefEnSE ATtORneY: Well, it does. And if they have no friends or family, they're in a bad predicament.

For example, Michelle, a forty-three-year-old White woman, talked about how, without a husband who could provide support at the time she was convicted, she felt pressure to sell drugs so she could make money and pay her legal debt: "I think it's ridiculous that I was [assessed] that amount of money. They told me they didn't want me selling drugs, well how do you think I'm going to pay this? And me a convicted drug felon, and come home, and support two kids, and I have no husband, and you want me to pay $\$ 360,000$. I'm just saying."

In addition to directly paying legal debt, relatives also indirectly facilitate the payment of fines and fees by providing their loved ones with, among other things, housing, transportation, childcare, and money for monthly bills. Not having family that can provide such indirect support frequently puts defendants in a bind. For example, Jenn is a forty-eight-year-old widow taking care of her eleven-year-old son Matthew by herself. For her several misdemeanor traffic offenses, such as driving with a suspended license, she was sentenced to probation and assessed fines and fees and commu- 
nity service. Her probation was eventually revoked, however, and she was sent to jail for a subsequent lane violation and for driving without insurance. She lost her house when she went to jail and is currently homeless, frequently moving from place to place with her son. During conversations with her probation officer, Jenn was told that if she did not complete her community service, she would have to increase the amount she was paying toward her monetary sanctions.

INTERVIEWER: Okay . . . talk me through a situation where that happened. Like what did the probation officer say?

JENN: You haven't got your hours in yet. You need to do, give me any more hours this week or you're going to have to be doubling up on your fine to kind of equal it up.

INTERVIEWER: So like one week you didn't go ten hours? So they'd have you pay?

JENN: An extra, like they want you to pay an extra payment ... They always said, to kind of equal it up, to make it, if you can't work this much, you need to pay more to kind of make it look like you're trying to, I don't know what. To make it look good for who, I don't know ... .

INTERVIEWER: So, making extra payments wasn't necessarily because you were behind on payments? But behind on community service hours?

JENN: Yes, yes.

Coming up with the extra money for fine payments was difficult for Jenn. She was bringing in only about $\$ 1,000$ a month, money used to take care of herself and her boy. Performing her community service, however, was also not an option. Jenn lacked the necessary indirect support for childcare that would have allowed her to adequately perform her community service.

Because [the probation officer] was like, "do you want to go back to jail? That's what's fixing to happen if you don't get this community service done like today," and I tried to make her understand I don't mind doing it at all. I like going to do it. Because a lot of times working at the Salvation Army I got to get my little extra clothes and all kind of stuff. So I didn't mind going at all. But with me, like having went and [her son is] only in fifth grade, he can't watch himself. So when I'm working it's hard for me to get people to watch him like, just to do community service when I'm already having to pay people to watch him while I'm working and we don't really have any family really. So, it's just hard.

In sum, not all people with legal debt have family that they can rely on to help pay their fines and fees. We find that such individuals seem to be at a greater risk of getting trapped into a cycle of perpetual criminal justice contact, ultimately functioning to sustain and reproduce class inequality (Harris 2016, 155-56). Thus, although fines and fees often harm families, the support they provide can also function to mitigate the pains of punishment felt by people who are assessed legal debt.

\section{DISCUSSION AND CONCLUSION}

How do monetary sanctions harm the families of adults with legal debt? Nearly 250 semistructured interviews in Georgia and Missouri reveal evidence that family members are often coerced by probation officers to pay their relatives' legal debt. If families cannot pay, their relatives may be threatened with force such as incarceration. Besides the potential loss of freedom for people assessed fines and fees, being threatened to pay a relative's LFOs by agents of the state engenders emotional distress and fear among family members. Further, when family send money to their loved ones while incarcerated, their funds may be legally diverted to paying LFOs. Not surprisingly, being assessed legal debt and relying on help from relatives can sow conflict between people who owe LFOs and their family and between family and court actors. The most obvious harm inflicted on families by monetary sanctions, however, is financial strain. Families rarely have extra money to lend to their relatives for payment of fines and fees. As a result, they often resort to burdensome methods of acquiring the money such as emptying their retirement savings and pawning the title of their cars. These payment strategies ultimately exacerbate the economic hardship that families experience. 
This research contributes to the literature on the negative effects of punishment on family, or symbiotic harms (Condry and Minson 2020). Most studies on symbiotic harms have focused on incarceration (Comfort 2016, 64), and for good reason. During the second half of the twentieth century, the United States saw an explosion in the size of its incarcerated population. The effects of this growth permeate to people beyond those locked behind bars. Through indirect and direct interaction with the criminal justice system, families are often harmed, suffering economic hardship, poor mental and physical health, and strained intimate relationships. For example, Megan Comfort (2007) describes how family members visiting loved ones in prisons and jails are subjected to the same types of control, such as being targeted for physical searches, as their justiceinvolved relatives. Symbiotic harms, however, are not isolated to incarceration but can result from, among other things, "arrest, trial, and community sanctions" (Condry and Minson $2020,2)$. To this list, we add monetary sanctions.

Despite a growing literature on criminal justice fines and fees, research on the relationship between LFOs and family is underdeveloped. This lack is unfortunate considering the vast scope and transferable nature of contemporary monetary sanctions function to stretch their costs far and wide (Harris, Evans, and Beckett 2010; Martin et al. 2018; O'Malley 2013; Quilter and Hogg 2018), making fines and fees especially likely to harm family and friends. One notable exception to the lack of research is a recent study by Leslie Paik and Chiara Packard (2019). They find that LFOs harm relatives by increasing negative emotions, financial strain, and family conflict. They rely, however, on interviews with young people convicted of crime and their parents, ultimately focusing on juvenile justice fines and fees. We built on this research by providing one of the first focused studies on how fines and fees harm the families of adults with legal debt.

We find that LFOs function to tether legally innocent relatives, most of whom are women, to the criminal justice system (Harris 2016, 72; see also Fernandes, Friedman, and Kirk 2022, this volume; Huebner and Giuffre 2022, this vol- ume; O'Neill, Smith, and Kennedy 2022, this volume; Sanchez et al. 2022, this volume). In some cases, relatives, for no reason other than that they live in the same house as someone who has been assessed LFOs, can have their financial information collected and scrutinized by probation officers. In Missouri, a household's total income, not just the income of the person convicted of the crime, can be used to assess whether someone has the ability to pay their legal debt. What is more, court actors actively leverage family and friends to collect LFOs. Probation officers told us that state force (such as threats to incarcerate people with legal debt) was, is, and should be used to extract wealth from relatives. As a result, court actors purposefully extort money from legally innocent family members (Pattillo and Kirk 2020). In short, the contemporary monetary sanctions regime is one that harms families across multiple life domains, hindering the emotional, economic, and interpersonal well-being of legally innocent people. Although families are harmed by the current use of fines and fees, we also find that they tend to mitigate some of the harm experienced by their justice-involved relatives. In other words, those without family support tend to suffer more from fines and fees than their familied counterparts. The former have a greater chance of getting trapped in a cycle of perpetual criminal justice contact, ultimately functioning to sustain and reproduce class inequality.

The findings of this research inspire normative concerns as every legally innocent "person has a prima facie moral right not to be harmed" (Condry and Minson 2020, 13). To mitigate the harm on family caused by legal debt, first, we suggest eliminating legal penalties for nonpayment. "Individuals who are not able to pay LFOs should not face subsequent criminal consequences such as incarceration, extended court supervision, or probation revocation or unsatisfactory termination" (Shannon et al. 2020,279 ). A consequence of this policy would be to reduce coercive tactics used by court actors against family and the emotional distress such tactics cause. For example, probation officers would no longer be able to engage in extortion by pressuring family through threats to incarcerate their loved ones. Second, we also 
suggest decoupling familial and household finances from assessments of indigence and ability to pay. As a probation officer from Missouri told us, if a household's total income is above the poverty line, a person's fees cannot be waived. This increases the amount of money people with legal debt are ultimately responsible for paying. But, given that family frequently provides financial support (Cook 2014; Gleicher and DeLong 2018), it also indirectly increases the economic hardship of legally innocent relatives. As a result, familial and household finances should not be used to assess indigence and ability to pay.

A few limitations of this study are significant. First, we did not interview family members of people with LFOs. Instead, we rely on our interviews with justice-involved individuals and court actors to marshal evidence of how family and friends are harmed by monetary sanctions. Future research should take up the task of including family members during data collection efforts. Second, our sample of people with legal debt was selected to maximize cases where justice-involved individuals had difficulty paying LFOs. As a result, our sample does not capture people who rely on family for assistance and in doing so escape further entanglement in the criminal legal system such as probation supervision. Third, our data on court actors were limited by the fact that some court actors (prosecutors) were reluctant to speak with us. Some of the reasons for this reluctance include a lack of time, distrust of the researchers, and fear of litigation and public scrutiny (despite repeated assurances of confidentiality).

To conclude, monetary sanctions are a common form of punishment in the current U.S. criminal justice system, assessed for a variety of offenses at the both the misdemeanor and the felony level. The harms they cause are not isolated to the people convicted of crimes, however. Instead, they spread through social networks, negatively influencing family and friends. The current use of fines and fees engenders tension and strain in the interpersonal relationships of relatives, exacerbates emotional distress and economic hardship, and encourages probation officers to coerce legally innocent family members.

\section{REFERENCES}

Aiello, Brittnie L., and Jill A. McCorkel. 2018. “'It Will Crush You Like a Bug': Maternal Incarceration, Secondary Prisonization, and Children's Visitation." Punishment \& Society 20(3): 351-74.

Albin-Lackey, Chris. 2014. Profiting from Probation: America's 'Offender-Funded' Probation Industry. New York: Human Rights Watch.

Carlson, Bonnie E., and Neil Cervera. 1992. Inmates and Their Wives: Incarceration and Family Life. Westport, Conn.: Greenwood Press.

Christian, Johnna. 2005. “Riding the Bus: Barriers to Prison Visitation and Family Management Strategies." Journal of Contemporary Criminal Justice 21(1): 31-48.

Comfort, Megan. 2007. "Punishment Beyond the Legal Offender." Annual Review of Law and Social Science 3(1): 271-96.

- 2008. Doing Time Together: Love and Family in the Shadow of the Prison. Chicago: University of Chicago Press.

- 2016. “'A Twenty-Hour-a-Day Job': The Impact of Frequent Low-Level Criminal Justice Involvement on Family Life." Annals of the American Academy of Political and Social Science 665(1): 63-79.

Condry, Rachel, and Shona Minson. 2020. “Conceptualizing the Effects of Imprisonment on Families: Collateral Consequences, Secondary Punishment, or Symbiotic Harms?" Theoretical Criminology. First published online January 28, 2020. DOI: https://doi.org/10.1177/136248061 9897078.

Cook, Foster. 2014. The Burden of Criminal Justice Debt in Alabama. Birmingham, Ala.: Jefferson County's Community Corrections Program. deVuono-powell, Saneta, Chris Schweidler, Alicia Walters, and Azadeh Zohrabi. 2015. Who Pays? The True Cost of Incarceration on Families. Oakland, Calif.: Ella Baker Center for Human Rights, Forward Together, and Research Action Design.

Emerson, Robert M., Rachel I. Fretz, and Linda L. Shaw. 2011. Writing Ethnographic Fieldnotes. Chicago: University of Chicago Press.

Fernandes, April D., Brittany Friedman, and Gabriela Kirk. 2022. “The 'Damaged' State vs. the 'Willful' Nonpayer: Pay-to-Stay and the Social Construction of Damage, Harm, and Moral Responsibility in a Rent-Seeking Society." RSF: The Russell Sage Foundation Journal of the Social Sciences 
8(1): 82-105. DOI: https://doi.org/10.7758/RSF .2022.8.1.10.

Gleicher, Lily, and Caitlin DeLong. 2018. The Cost of Justice: The Impact of Criminal Justice Financial Obligations on Individuals and Families. Chicago: Illinois Criminal Justice Information Authority.

Goffman, Alice. 2014. On the Run: Fugitive Life in an American City. Chicago: University of Chicago Press.

Hagan, John, and Holly Foster. 2012. “Intergenerational Educational Effects of Mass Imprisonment in America." Sociology of Education 85(3): 25986.

Harris, Alexes. 2016. A Pound of Flesh: Monetary Sanctions as Punishment for the Poor. New York: Russell Sage Foundation.

Harris, Alexes, Heather Evans, and Katherine Beckett. 2010. “Drawing Blood from Stones: Legal Debt and Social Inequality in the Contemporary United States." American Journal of Sociology 115(6): 1753-99.

Harris, Alexes, Mary Pattillo, and Bryan L. Sykes. 2022. "Studying the System of Monetary Sanctions." RSF: The Russell Sage Foundation Journal of the Social Sciences 8(1): 1-33. DOI: https://doi .org/10.7758/RSF.2022.8.1.01.

Harris, Alexes, and Tyler Smith. 2022. “Monetary Sanctions as Chronic and Acute Health Stressors: The Emotional and Physical Strain of People Who Owe Court Fines and Fees." RSF: The Russell Sage Foundation Journal of the Social Sciences 8(2): 36-56. DOI: https://doi.org/10.7758 /RSF.2022.8.2.02.

Headworth, Spencer. 2019. “Getting to Know You: Welfare Fraud Investigation and the Appropriation of Social Ties." American Sociological Review 84(1): 171-96.

Huebner, Beth M., and Andrea Giuffre. 2022. “Reinforcing the Web of Municipal Courts: Evidence and Implications Post-Ferguson." RSF: The Russell Sage Foundation Journal of the Social Sciences 8(1): 108-27. DOI: https://doi.org/10.7758 /RSF.2022.8.1.05.

Huebner, Beth M., and Sarah K.S. Shannon. 2022. “Private Probation Costs, Compliance, and the Proportionality of Punishment: Evidence from Georgia and Missouri." RSF: The Russell Sage Foundation Journal of the Social Sciences 8(1): 179-99. DOI: https://doi.org/10.7758/RSF .2022.8.1.08.

Kaplan, Alexander, Ahmed Lavalais, Tim Kline, Jenna
Le, Rachel Draznin-Nagy, Ingrid Rodríguez, Jenny van der Heyde, Stephanie Compos-Bui, and Jeffrey Selbin. 2016. High Pain, No Gain: How Juvenile Administrative Fees Harm Low-Income Families in Alameda County, California. Berkeley: Berkeley Policy Advocacy Clinic.

Katzenstein, Mary Fainsod, and Maureen R. Waller. 2015. "Taxing the Poor: Incarceration, Poverty Governance, and the Seizure of Family Resources." Perspectives on Politics 13(3): 63856.

Lopoo, Leonard M., and Bruce Western. 2005. “Incarceration and the Formation and Stability of Martial Unions." Journal of Marriage and Family 67(3): 721-34.

Martin, Karin D., Bryan L. Sykes, Sarah K.S. Shannon, Frank Edwards, and Alexes Harris. 2018. “Monetary Sanctions: Legal Financial Obligations in US Systems of Justice." Annual Review of Criminology 1(1): 471-95.

O'Malley, Pat. 2013. "Monetized Justice: Money and Punishment in Consumer Societies." In The Sage Handbook of Punishment and Society, edited by Johnathan Simon and Richard Sparks. London: Sage Publications.

O'Neill, Kate K., Tyler Smith, and Ian Kennedy. 2022. "County Dependence on Monetary Sanctions: Implications for Women's Incarceration." RSF: The Russell Sage Foundation Journal of the Social Sciences 8(2): 157-72. DOI: https://doi.org /10.7758/RSF.2022.8.2.08.

Page, Joshua, Victoria Piehowski, and Joe Soss. 2019. "A Debt of Care: Commercial Bail and the Gendered Logic of Criminal Justice Predation." RSF: The Russell Sage Foundation Journal of the Social Sciences 5(1): 150-72. DOI: https://doi.org /10.7758/RSF.2019.5.1.07.

Pager, Devah. 2003. "The Mark of a Criminal Record." American Journal of Sociology 108(5): 93775.

Paik, Leslie, and Chiara Packard. 2019. Impact of Juvenile Justice Fines and Fees on Family Life: Case Study in Dane County, WI. Houston, Tex.: Arnold Ventures.

Pattillo, Mary, Erica Banks, Brian Sargent, and Daniel J. Boches. 2022. “Monetary Sanctions and Housing Instability." RSF: The Russell Sage Foundation Journal of the Social Sciences 8(2): 57-75. DOI: https://doi.org/10.7758/RSF.2022.8.2.03.

Pattillo, Mary, and Gabriela Kirk. 2020. “Pay Unto Caesar: Breaches of Justice in the Monetary 
Sanctions Regime." UCLA Criminal Justice Law Review 4(1): 49-77.

Pleggenkuhle, Breanne. 2018. “The Financial Cost of a Criminal Conviction: Context and Consequences." Criminal Justice and Behavior 45(1): $121-45$.

Quilter, Julia, and Russell G. Hogg. 2018. “The Hidden Punitiveness of Fines." International Journal for Crime, Justice and Social Democracy 7(3): 1040.

Roettger, Michael E., and Jason D. Boardman. 2012. “Parental Incarceration and Gender-Based Risks for Increased Body Mass Index: Evidence from the National Longitudinal Study of Adolescent Health in the United States." American Journal of Epidemiology 175(7): 636-44.

Ruhland, Ebony. 2020. “Social Worker, Law Enforcer, and Now Bill Collector: Probation Officers' Collection of Supervision Fees." Journal of Offender Rehabilitation 59(1): 44-63.

Sanchez, Amairini, Michele Cadigan, Dayo AbelsSullivan, and Bryan L. Sykes. 2022. “Punishing Immigrants: The Consequences of Monetary Sanctions in the Crimmigration System." RSF: The Russell Sage Foundation Journal of the Social Sciences 8(2): 76-97. DOI: https://doi.org/10 $.7758 / R S F .2022 .8 .2 .04$.
Shannon, Sarah K.S., Beth M. Huebner, Alexes Harris, Karin D. Martin, Mary Pattillo, Becky Pettit, Bryan L. Sykes, and Christopher Uggen. 2020. "The Broad Scope and Variation of Monetary Sanctions: Evidence From Eight States." UCLA Criminal Justice Law Review 4(1): 269-81.

Swann, Christopher A., and Michelle Sherman Sylvester. 2006. “The Foster Care Crisis: What Caused Caseloads to Grow?" Demography 43(2): 309-35.

Wakefield, Sara, and Christopher Wildeman. 2011. "Mass Imprisonment and Racial Disparities in Childhood Behavioral Problems." Criminology \& Public Policy 10(3): 793-817.

Walker, Sheri Pruitt. 2011. "The Effects of the Incarceration of Fathers on the Health and Wellbeing of Mothers and Children." Ph.D. diss, University of Maryland, College Park.

Western, Bruce, Anthony A. Braga, Jaclyn Davis, and Catherine Sirois. 2015. “Stress and Hardship after Prison." American Journal of Sociology 120(5): 1512-47.

Wildeman, Christopher, Jason Schnittker, and Kristin Turney. 2012. “Despair by Association? The Mental Health of Mothers with Children by Recently Incarcerated Fathers." American Sociological Review 77(2): 216-43. 